\section{Pharmaceutical market, environmental public policies and water quality: the case of the São Paulo Metropolitan Region, Brazil}

\author{
Mercado farmacêutico, políticas públicas ambientais \\ e qualidade da água: o caso da Região Metropolitana \\ de São Paulo, Brasil
}

Rafaela Barbosa de Andrade Aragão 1

Décio Semensatto 1

Leandro Augusto Calixto 1

Geórgia Labuto 1 doi: 10.1590/0102-311X00192319

\begin{abstract}
Water pollution has been an increasing concern for the authorities responsible for planning and executing public policies. In this qualitative research, we have discussed the most sold pharmaceuticals in the São Paulo Metropolitan Region, Brazil, and compared public policies focused on pharmaceuticals and environmental issues among countries/regions. For that, data provided by Close-Up International related to the sales of medicines in the São Paulo Metropolitan Region between April/2016 and April/2017 were collected and processed to identify and quantify the pharmaceutical products. The 300 most sold medicines in the São Paulo Metropolitan Region fall in 26 therapeutic classes, which include 159 drugs. The most sold pharmaceutical products group is nonsteroidal anti-inflammatory drugs (NSAIDs) representing approximately $44.3 \%$ of the total. The ten most sold pharmaceuticals sum up 1200 tons. Dipyrone is the first place in mass representing around 488 tons, followed by metformin with around 310 tons commercialized. Public policies focused on pharmaceuticals in the environment still need adjustments to improve reinforcement, even in developed countries. There is no international standard on how to conduct the issue, each country adopting the public policy that best matches to the local. Brazil, despite having some legislation that approaches the theme, still lacks effective public policies and stakeholder awareness. In this aspect, the need for improvement of the reverse logistics system, consumer orientation to the adequate disposal of unused/expired medicines, and the adoption of the unit-dose system as a therapeutic strategy is evident.
\end{abstract}

Correspondence

D. Semensatto

Instituto de Ciências Ambientais, Químicas e Farmacêuticas, Universidade Federal de São Paulo.

Rua Professor Artur Riedel 275, Diadema, SP 09172-270, Brasil.

decio.semensatto@unifesp.br

1 Instituto de Ciências Ambientais, Químicas e Farmacêuticas, Universidade Federal de São Paulo, Diadema, Brasil. 


\section{Introduction}

Access to quality water has been recognized by the United Nations as an essential right in realizing all other human rights (Resolution n. 64/292). Worryingly, however, the quality of water bodies has been deteriorating as a result of misuse of natural resources, causing scarcity, both in terms of quantity and quality 1 . This situation requires urgent attention not only from environmental professionals but also from those in the health sciences 2 .

Pharmaceuticals drugs are a particular group of pollutants that since the 1970s have aroused interest of the scientific community due to the growing frequency and concentration of both pharmaceuticals and metabolites in water, sediments and aquatic organisms 3. Such compounds are emerging pollutants, and most lack any ecotoxicological information or environmental regulation, despite the potential to cause many adverse effects on biota, including humans ${ }^{4}$. Although some of them are degradable, their constant input into water bodies results in similar behavior to that of persistent substances and can cause a variety of impacts on aquatic life and health 5 .

The projected growth in global medicine use was expected to increase by 4.5 trillion doses by 2020, an addition of 24\% from 20156 . The IMS Institute for Healthcare Informatics (New Jersey, United States) also points out that global medication spending was expected to rise by $29-32 \%$ by 2020 , with an estimated $50 \%$ of the world's population consuming more than one dose per person per day. It was forecast that global absolute pharmaceutical spending would increase from USD 182 billion in the period 2010-2015 to USD 349 billion in the period 2016-2020, i.e., an expansion of 91.8\%. Concerning Brazil, the prognosis indicated that consumption would reach 2.82 doses per person per day by 2020 (an increase of 38\%). The consequence of this global and national increase in pharmaceutical production and consumption is the potential greater quantity of these substances being released into the environment than it currently is. Some papers presented relatively accurate predictions of pharmaceuticals drugs concentration in wastewater treatment plant (WWTP) influents/effluents and surface water based on sales and consumption data 7,8,9. Thus, it is reasonable to infer that the higher sales and consumption are, the higher the concentration of pharmaceuticals drugs in the environment.

As in other regions of the world, concentrations of different types of pharmaceuticals drugs have been found in the water and sediment of the Billings and Guarapiranga reservoirs, which receive untreated sewage, despite supplying together drinking water to 6.4 million people in the São Paulo Metropolitan Region 10,11. The water collected and distributed from these reservoirs only goes through conventional treatment systems, which only makes a negligible reduction in concentrations 12 .

In this work, we have presented an overview of pharmaceutical sales in the São Paulo Metropoli$\tan$ Region, which in its turn may indicate their potential release into local water bodies. Furthermore, we have compared the public policies associated with unit-dose systems (UDS) and disposal and reverse logistics employed in Brazil and other countries and regions in order to offer recommendations to improve public policies in planning and execution.

\section{Material and methods}

\section{São Paulo Metropolitan Region}

The São Paulo Metropolitan Region consists of 39 cities (Figure 1) with an estimated population of 21.5 million in 2018, according to the Brazilian Institute of Geography and Statistics (IBGE). The São Paulo Metropolitan Region has robust economic activity with its regional Gross Domestic Product (GDP) of USD 250 billion. Nevertheless, the region presents several inequalities in terms of the proportion of health units (hospitals, emergency units, clinics, diagnosis centers), GDP per capita and the proportion of households served by sanitation facilities (Table 1). If, on the one hand, the proportion of health units and GDP per capita indirectly expresses the potential of the population of each city to access medicine, on the other hand, the proportion of the population served by the sanitation facilities denotes the potential for load of pharmaceuticals and their metabolites released into local aquatic ecosystems via untreated sewage. These numbers indicate that regional management of potential pharmaceutical loads in water bodies is challenging and quite heterogeneous among municipalities. 


\section{Figure 1}

Cities of the São Paulo Metropolitan Region, Brazil.

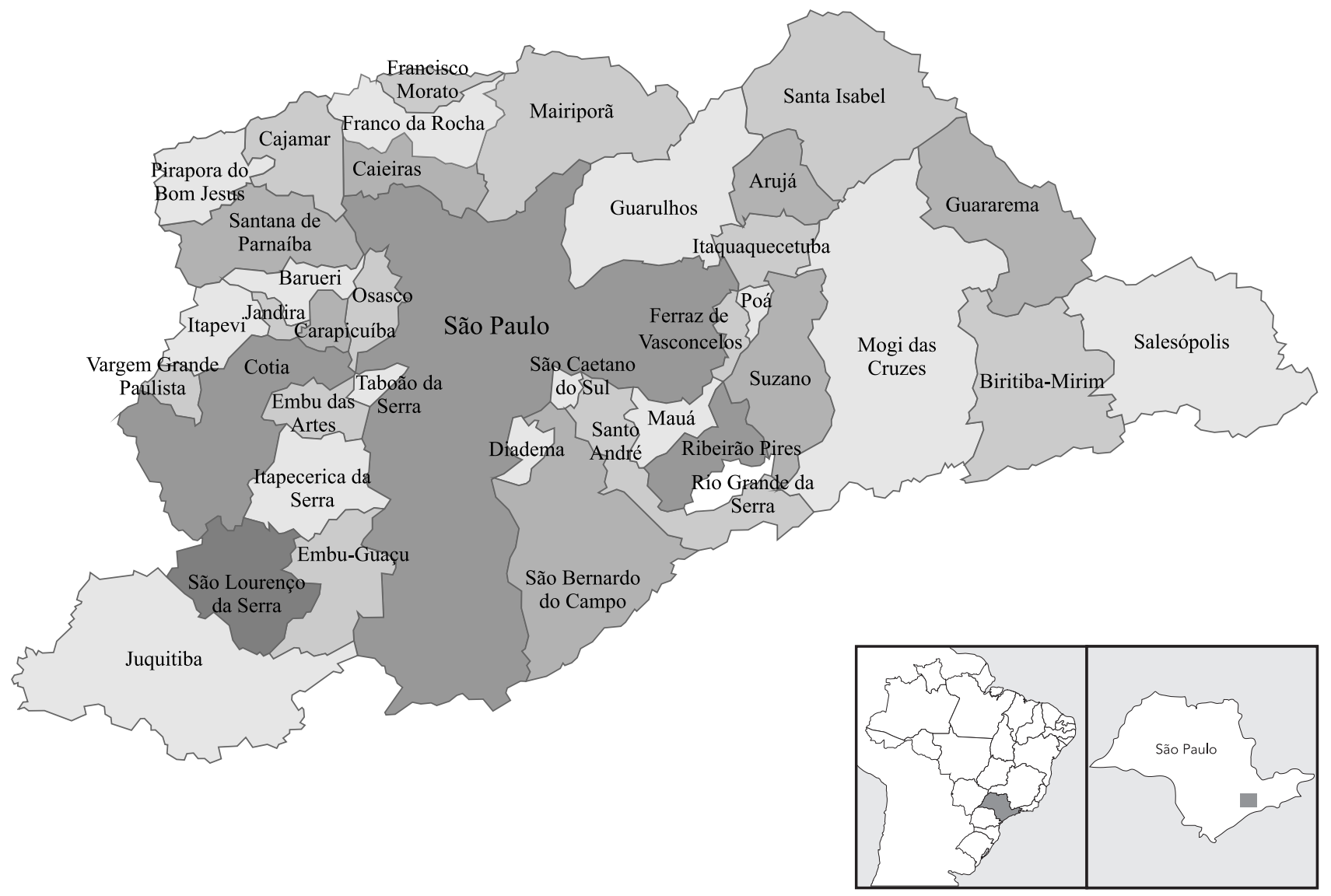

\section{Source of data and analysis}

We have analyzed a set of secondary data obtained from scientific, technical, legal, and legislative literature. Close-Up International provided, under our request, a list of the 300 most marketed medicines in the São Paulo Metropolitian Region from April/2016 to April/2017, in which the masses $(\mathrm{kg})$ of pharmaceuticals drugs circulating in the region were calculated based on the information on the medicine, the dosage form (tablet, suspension etc.), quantity by package, and the dose. As some pharmaceuticals drugs are made up of more than one medicine, we ascertained the mass of each one by adding up the masses of all medicines with the pharmaceuticals drugs in question. Close-Up International's information considers wholesale and retail marketing in drugstores and by public and private sector hospitals. In Brazil, over-the-counter drugs are sold solely in drugstores; thus, data used in this work encompasses the whole market regarding over-the-counter drugs. Data did not include veterinary drugs, dermatological ingredients, and medicines traded in unregulated markets.

Following the survey and the standardization of the masses, we then organized the pharmaceuticals according to their respective therapeutic classes, based on the 2010 national therapeutic form 2010 of the Brazilian Ministry of Health 13 and the guide to generic medicines 14 . As in some cases the same pharmaceutical may cover two or more therapeutic classes, we have adopted the class indicated in the pharmaceutical specialty dictionary 15. 
Table 1

List of cities that form the São Paulo Metropolitan Region, Brazil, organized by population size.

\begin{tabular}{|c|c|c|c|c|c|}
\hline City & $\begin{array}{l}\text { Inhabitants } \\
\text { (2010) }\end{array}$ & $\begin{array}{l}\text { Health units } \\
\text { (2009) }\end{array}$ & $\begin{array}{l}\text { Health units } / 10,000 \\
\text { inhabitants }\end{array}$ & $\begin{array}{l}\text { GDP per capita - } \\
\text { USD (2016) }\end{array}$ & $\begin{array}{c}\text { Households served by } \\
\text { sanitation facilities in } 2017 \text { (\%) }\end{array}$ \\
\hline São Paulo & $11,253,503$ & 2,541 & 2.3 & $14,849.99$ & 95.7 \\
\hline Guarulhos & $1,221,979$ & 242 & 2.0 & $10,503.63$ & 87.7 \\
\hline São Bernardo do Campo & 765,463 & 308 & 4.0 & $13,332.55$ & 95.9 \\
\hline Santo André & 676,407 & 299 & 4.4 & $9,432.21$ & 98.7 \\
\hline Osasco & 666,740 & 177 & 2.7 & $27,800.23$ & 89.1 \\
\hline Mauá & 417,064 & 78 & 1.9 & $7,938.44$ & 94.5 \\
\hline Mogi das Cruzes & 387,779 & 140 & 3.6 & $8,743.39$ & 85.3 \\
\hline Diadema & 386,089 & 77 & 2.0 & $8,291.29$ & 93.3 \\
\hline Carapicuíba & 369,584 & 36 & 1.0 & $3,439.37$ & 79.5 \\
\hline Itaquaquecetuba & 321,770 & 37 & 1.1 & $4,746.14$ & 67.6 \\
\hline Suzano & 262,480 & 86 & 3.3 & $8,553.21$ & 93.4 \\
\hline Taboão da Serra & 244,528 & 44 & 1.8 & $7,873.50$ & 97.9 \\
\hline Barueri & 240,749 & 107 & 4.4 & $46,246.73$ & 98.2 \\
\hline Embu das Artes & 240,230 & 25 & 1.0 & $9,843.94$ & 71.8 \\
\hline Cotia & 201,150 & 55 & 2.7 & $12,238.02$ & 51.0 \\
\hline Itapevi & 200,769 & 28 & 1.4 & $13,955.80$ & 62.4 \\
\hline Ferraz de Vasconcelos & 168,306 & 21 & 1.2 & $3,982.24$ & 81.8 \\
\hline Francisco Morato & 154,472 & 23 & 1.5 & $2,101.01$ & 41.9 \\
\hline Itapecerica da Serra & 152,614 & 29 & 1.9 & $5,929.10$ & 29.2 \\
\hline São Caetano do Sul & 149,263 & 165 & 11.1 & $21,767.37$ & 99.6 \\
\hline Franco da Rocha & 131,604 & 24 & 1.8 & $4,335.34$ & 62.7 \\
\hline Ribeirão Pires & 113,068 & 50 & 4.4 & $6,491.23$ & 72.9 \\
\hline Santana de Parnaíba & 108,813 & 12 & 1.1 & $17,080.83$ & 41.1 \\
\hline Jandira & 108,344 & 17 & 1.6 & $7,403.98$ & 74.8 \\
\hline Poá & 106,013 & 27 & 2.5 & $9,857.84$ & 99.1 \\
\hline Caieiras & 85,529 & 31 & 3.6 & $7,258.80$ & 73.9 \\
\hline Mairiporã & 80,956 & 30 & 3.7 & $4,538.34$ & 21.9 \\
\hline Arujá & 74,905 & 25 & 3.3 & $14,446.77$ & 68.6 \\
\hline Cajamar & 64,114 & 18 & 2.8 & $46,490.06$ & 89.1 \\
\hline Embu-Guaçu & 62,769 & 9 & 1.4 & $4,083.01$ & 36.8 \\
\hline Santa Isabel & 50,453 & 14 & 2.8 & $5,810.00$ & 46.7 \\
\hline Rio Grande da Serra & 43,974 & 13 & 3.0 & $3,078.49$ & 51.5 \\
\hline Vargem Grande Paulista & 42,997 & 10 & 2.3 & $9,167.20$ & 32.7 \\
\hline Juquitiba & 28,737 & 12 & 4.2 & $3,733.51$ & 13.9 \\
\hline Biritiba Mirim & 28,575 & 5 & 1.7 & $6,104.27$ & 47.8 \\
\hline Guararema & 25,844 & 2 & 0.8 & $12,954.15$ & 46.0 \\
\hline Pirapora do Bom Jesus & 15,733 & 5 & 3.2 & $3,898.05$ & 50.3 \\
\hline Salesópolis & 15,635 & 4 & 2.6 & $3,036.52$ & 51.6 \\
\hline São Lourenço da Serra & 13,973 & 5 & 3.6 & $3,333.90$ & 28.3 \\
\hline Total & $19,682,975$ & 4,831 & 2.5 & $10,632.58$ & 89.5 \\
\hline
\end{tabular}

GDP: Gross Domestic Product.

Notes: data of inhabitants, health units (hospitals, ambulatories, clinics, diagnosis centers) and GDP were extracted from 2010 Demographic Census of the Brazilian Institute of Geography and Statistics (IBGE. http://www.ibge.gov.br). Data of sanitation facilities were extracted from the Brazilian National System of Information about Sanitation (SNIS. http://www.snis.gov.br/). Currency conversion from Brazilian Real to US Dollar from the Brazilian Central Bank (BRL 1,00 = USD 0,2602). 
Comparisons on public policies were based on the analysis of the regulations on the UDS, the disposal and reverse logistics of unused/expired medicines in the United States, Canada, European Union and, Brazil. The inclusion of Canadian information stems from the fact that this country presents the broadest management plan for chemicals, which includes pharmaceutical drugs, an interesting aspect for comparative assessments.

\section{Results}

The 300 most sold medicines in the São Paulo Metropolitan Region fall into 26 therapeutic classes and 159 pharmaceuticals drugs, totaling 1,499 tons (Supplementary Material: http://cadernos.ensp. fiocruz.br/static//arquivo/suppl-e00192319_1464.pdf). Of this total, 1,200 tons ( 85\%) refer to only ten substances (Table 2). The therapeutic class with the highest sold mass is nonsteroidal antiinflammatory drugs, representing $44.3 \%$, followed by antidiabetics, electrolytes/nutrition, and antihypertensives, accounting for $20.8 \%, 6.7 \%$, and $4.5 \%$ respectively. It is important to emphasize the lack of information on the pharmacokinetics and toxicological behavior of metabolites for most listed substances. It represents a critical data gap for the environmental monitoring and control of these substances in the environment. Thus, the present data might help to define which pharmaceuticals should be prioritized, in terms of potential input load into natural ecosystems and drinking water, for the development of studies regarding their impacts on biota, environment, and humans. Of the ten pharmaceuticals with the largest mass marketed, only four contain information regarding the percentage of excretion in its unaltered form in their respective leaflets.

Hormones are not among the top sold medicines in terms of mass because of their typical low dosage and concentration, although they exert significant impacts on organisms and ecosystems. Data on sales at the São Paulo Metropolitan Region reveal that 11 hormones were traded in the region during the period analyzed, dominated by dienogest and estradiol, which together account for $85 \%$ of the total mass of traded hormones (Table 3).

Antimicrobials account for 26.14 tons, which represents $1.74 \%$ of the total mass of pharmaceuticals drugs traded. Cephalexin, amoxicillin and, ciprofloxacin add up to $72 \%$ of the mass of antimicrobials here listed.

Table 2

Ranking of the 10 most sold pharmaceutical drugs at the São Paulo Metropolitan Region, Brasil, between April/2016 and April/2017, after processing data provided by Close-Up International.

\begin{tabular}{lccc}
\hline Active principle & Commercialized mass $\mathbf{( k g )}$ & Drug class & Excretion in unaltered form (\%) \\
\hline Dipyrone & 488,445 & Nonsteroidal anti-inflammatory drugs & $*$ \\
Metformin & 310,067 & Antidiabetics & 100 \\
Paracetamol & 94,881 & Nonsteroidal anti-inflammatory drugs & $3.5-5.0$ \\
Phenylephrine & 57,202 & Nasal decongestant & - \\
Chlorpheniramine & 56,666 & Anti-allergy and antihistamines & - \\
Losartan & 42,337 & Antihypertensives & 4.0 \\
Sodium bicarbonate & 41,709 & Antacids & $*$ \\
Citric acid & 39,895 & Antacids & * \\
lbuprofen & 37,110 & Nonsteroidal anti-inflammatory drugs & * \\
Zinc & 33,747 & Electrolytes and nutrition & .0 \\
\hline
\end{tabular}

* Values not specified at the package leaflets. 
Table 3

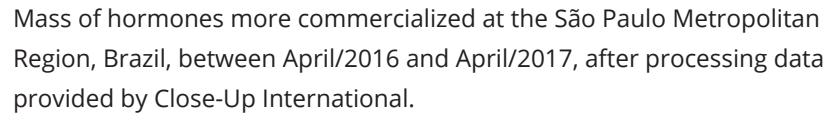

\begin{tabular}{lc}
\hline Active ingredient & Mass sold $\mathbf{( k g )}$ \\
\hline Dienogest & $1,564.92$ \\
Estradiol & $1,339.44$ \\
Drospirenone & 127.88 \\
Testosterone & 126.64 \\
Ciproterone & 67.56 \\
Ethynilestradiol & 58.63 \\
Levonorgestrel & 56.46 \\
Noretisterone & 54.07 \\
Levotiroxine & 14.16 \\
Desogestrel & 4.90 \\
Gestodene & 0.95 \\
Total & $3,415.62$ \\
\hline
\end{tabular}

\section{Discussion}

Dipyrone is broadly consumed in Brazil, although it is banned in some countries because of its relationship with agranulocytosis and other blood dyscrasias 16 . Its original form and metabolites are easily found in wastewater from sewage treatment plants in many cities, as such, it is no surprise that is the pharmaceutical with the highest concentration reported in Latin America among many emergent pollutants 17 . A prioritization ranking for environmental monitoring of emergent pollutants in aquatic environments positioned dipyrone in a group of low toxicity, but high exposure potential scores 18. Such level of exposure is a function of the high consumption due to its low cost and strong analgesic effect, which is enhanced by the possibility of purchasing over-the-count drugs 19 . Dipyrone and its metabolites caused toxic effects in fish, mostly DNA damage, reaching the ultrastructural level, in concentrations from 50ng.L-1 16. In most of the cities that form the São Paulo Metropolitan Region, the sewage systems do not serve a significant part of inhabitants (Table 1); thus, untreated sewage flows to the main reservoirs that supply the population within the São Paulo Metropolitan Region: Guarapiranga and Billings 20. The sewage collected is subjected to conventional physical-chemical treatments, which do not remove satisfactorily dipyrone or its metabolites, the last recognized as more persistent and toxic; removal from water ranges from $45 \%$ to $68 \%$ (4-formylaminoantipyrine: 4-FAA and 4-methylaminoantipyrine: 4-MAA, respectively) 19 . Hence, taking into account the considerable mass of this active component sold at the São Paulo Metropolitan Region, we can infer that the exposure level for local biota is potentially high.

Metformin is the most prescribed drug for anti-diabetic treatment worldwide for type- 2 diabetes (non-insulin-dependent) 21. In Brazil, metformin dominates the oral hypoglycemic market with a market share of $57.5 \%$ of this class of pharmaceuticals drugs in 2012 22. Metformin was freely distributed to patients through the Farmácia Popular Program, a program launched in 2004 that was discontinued in 2018.

Prevalence of type-2 diabetes in Brazil has grown, with obesity as the main risk factor, reaching 11.2\% in São Paulo in 2013 23, and it is inferred that type-2 diabetes costed USD 1,844 per patient in 2010 in São Paulo 24. It was discussed that the government should enforce policies for the prevention of diabetes and its secondary complications to tackle the rising costs for the public health system, which in our view may consequently reduce the load of metformin in the environment. However, prescriptions of metformin are expected to rise because it has been successfully tested as an anticancer 
agent 25 and weight loss drug both for diabetic and non-diabetic individuals 26 , also being used for treatment of polycystic ovaries and excreted in its original form through urine 21. Despite metformin and its biodegraded product granylurea being recognized as recalcitrant in surface water 8 , it remains poorly monitored in the environment and only a few papers report its occurrence and fate 27. Metformin acts as an endocrine disruptor and inhibits the growth of organisms, namely fish, Daphnia, algae, earthworm and humans 28,29, although its ecological risk is classified as low 30 .

Revised data about metformin in the environment revealed that the maximum concentration ever found was $248 \mu \mathrm{g} / \mathrm{L}$ in raw water in the United States; surface water concentrations of metformin are also related to the population age structure and local sewage contributions 27 . To date, there is no data about the concentration of metformin or granylurea in water and wastewater from the São Paulo Metropolitan Region. However, these two compounds may be present in most water bodies and urban reservoirs of the São Paulo Metropolitan Region, taking into account the relationship between prescription levels and concentration in the environment 27 , not to mention the fact that a proportion of untreated sewage flows directly into water bodies and WWTPs do not remove these compounds completely 31 .

Paracetamol (acetaminophen) is an analgesic broadly consumed in Brazil as an alternative to dipyrone and ibuprofen. It was found in the superficial waters, influent and effluent of WWTPs in many countries 19,29,32. Paracetamol was found in Brazil in raw water (0.01-1,222.6ng.L-1) and drinking water $\left(<0.20-453.6 \mathrm{ng} . \mathrm{L}^{-1}\right)$ 33. Its presence was reported in the São Paulo Metropolitan Region in $74 \%(n=42)$ of superficial water samples collected at Guarapiranga Reservoir but without any significant concentration 11 . The excretion rate is $80.9 \%$ and its removal from water and wastewater varies between $95 \%$ and $100 \%$ 19,32. Paracetamol is often ranked in intermediary positions in the lists for environmental monitoring 18,29, despite its high frequency in samples and high concentration. Additionally, its active metabolite $\mathrm{N}$-acetyl-p-benzoquinone imine is considered potentially toxic to the liver and kidneys 34 .

Phenylephrine and chlorpheniramine are poorly mentioned and have never been reported in environmental matrices in Brazil, probably because they are MEOCS (Matthew Effect Orphaned Chemicals) 35 . Phenylephrine is a nasal decongestant used in single- and multiple-ingredient overthe-counter drugs ${ }^{36}$. However, some papers classified phenylephrine as a drug of abuse, considering that it is a metabolite of the stimulant ephedrine 37,38 . Its removal was inferred by $55 \%$ after sewage was submitted to pre-treatment for solid removal, primary treatment to eliminate suspended material, activated sludge biological treatment and final clarification 39. There is a lack of information about the toxicity, despite it may be moderate 40 .

Losartan is an anti-hypertensive that became an affordable treatment and increased its market share in Brazil from < 5\% to $53 \%$ in ten years 41 . It is present in waters in many places in Latin America, including São Paulo Metropolitan Region 11,17,42,43. Losartan seems to have low toxicity 44, but potentially bioaccumulates and can generate cyanide ions by reaction with sodium hypochlorite in WWTP 45.

Ibuprofen was one of the pharmaceuticals with the highest frequency in drinking water and presented the highest concentration of all in Latin America 17,43. The minimum and maximum concentrations varied in Brazilian raw water (0.02-4,155.5ng.L-1) and drinking water (<0.66-16.9ng.L-1) 33. Despite its high frequency, ibuprofen is a low priority for monitoring 18; it may cause adverse effects in some organisms and its presence in WWTP effluent represents a high potential of environmental risk 32 . Advanced oxidation process (AOP) removed $>90 \%$ of Ibuprofen from water in laboratory experiments 33 .

Natural and synthetic hormones can undergo interconversion through their metabolization by aerobic and anaerobic organisms, which also contributes to environmental pollution in densely populated urban centers 46 .

Dienogest is prescribed as a next-generation oral contraceptive. It undergoes rapid direct photolysis and forms complex products with $\mathrm{pH}$ between 2 and 747 . Complete and facile photodegradation of dienogest occurs in sunlit surface water, although it might be environmentally persistent through product-to-parent reversion and formation of bioactive transformation products 47 . Data about dienogest occurrence in wastewater and surface water is rare because analytical methods to detect it in such matrices have only been developed recently 48 . Only a few papers reported the presence of 
dienogest in environmental matrices, but ecotoxicological effects remain unknown 49. Considering that dienogest is the most sold hormone in terms of mass within the São Paulo Metropolitan Region, it ought to be assessed and monitored in water bodies to evaluate possible environmental/health risks.

Antimicrobials are a therapeutic class that arouses great concern due to their environmental impacts 50 . Although its commercialized mass is small in comparison to other pharmaceuticals drugs, it is important to note that this specific group must be observed carefully, as there are several environmental and human risks associated with its inappropriate use and disposal.

\section{Public policies: United States, European Union, Canada and Brazil}

\section{- Monitoring pharmaceutical programs in water bodies}

Most countries do not execute continuous drug monitoring programs in drinking water because of the high cost, low availability of technologies and analytical methods and lack of laboratory infrastructure 51. Therefore, most of the available data on the occurrence of pharmaceuticals drugs in water bodies and drinking water comes from academic projects carried out to develop, test and adjust methods of detection and analysis of drugs in the environment.

The U.S. Environmental Protection Agency (EPA) established the Unregulated Contaminant Monitoring Rule (UCMR), which is in its fourth edition, in order to publish once every five years a list of up to 30 unregulated contaminants that public water systems must monitor 52 . The 2016 edition did not mention any pharmaceutical drug, but the former edition registered seven hormones: $17-\beta$-estradiol, 17- $\alpha$-ethinyl estradiol, 16- $\alpha$-hidroxiestradiol, equilin, estrone, testosterone, and 4-androstene3,17-dione. During the years covered by the UCMR, toxicological essays and ecological risk assessments are carried out based on concentrations reported in monitoring. Depending on the results, EPA includes the contaminant on the Candidate Contaminant List (CCL) or removes it from the monitoring list. The CCL prioritizes the contaminants to be assessed in terms of toxicological effects. After the publication of the CCL, the EPA decides on at least five contaminants present in the list to undergo regulation. If a contaminant fulfills all the criteria, EPA publishes the Maximum Contaminant Level Goal and the National Primary Drinking Water Regulation. Even though these mechanisms are essential to regulate emerging contaminants, they are not enough to meet the demand for monitoring drugs in water bodies.

The European Union follows the Directive 2013/29/EU, which requires a "watch list" to be created by the European Commission with the contaminants to be monitored. Depending on the results, a prioritization list includes the contaminants that are often detected in water with concentrations that can cause effects on human health and ecosystems. The most recent list released in 2018 followed the analysis of the Joint Research Centre 53. The European Commission is developing strategic approaches to tackle pharmaceuticals in the environment, but each State-Member regulates the pharmaceuticals and the maximum levels within its territory 54. The Strategy Micropoll implemented in Switzerland is a good example of how to tackle the pollution caused by micropollutants, such as pharmaceuticals 55 .

In 2006, the Government of Canada launched the Chemicals Management Plan (CMP) to reduce the risks of chemicals to human health and the environment. The plan provides the basis to formulate national public policies and includes investments to advance research and environmental monitoring, including pharmaceuticals and personal care products. Since then, assessments have included over 4,300 chemical priorities under the CMP; more than 2,700 substances have been assessed, and over 130 were concluded to be toxic 56 .

Brazilian national legislation does not regulate the pharmaceuticals in drinking water and the environment. The monitoring initiatives come from academics and some environmental agencies, such as the São Paulo State Environmental Company (CETESB). Brazil still lacks an official prioritization list of pharmaceuticals to be assessed and monitored in water, so the present paper contributes by clarifying this situation and offering information for accomplishing this task. 


\section{- Unit-dose systems}

The rational use of medicines assumes that patients will receive the appropriate drugs for their clinical needs, in doses that meet their requirements and for an adequate period at the lowest cost for them and their community 57 . The United States, Canada, and Europe adopt UDS, which significantly reduce losses, costs, and prescription errors 58 . The principle is always the same: patients purchase medicines in the exact prescribed dosage and period; hospitals deliver the unit-doses according to the patient's requirements.

Brazilian patients often acquire more medicines than prescribed because packages are sold either sealed, in primary (blister packaging), or secondary packaging (cartons), which impedes fractioning. Despite national regulation intended to establish the possibility of fractioning packages to provide the unit-doses, drugstores have not adopted the UDS. Excessive dispensing reached up to 200\% for azithromycin and most of the medicines were distributed up to $30 \%$ in excess by the pharmacy of a public health unit at the São Paulo Metropolitan Region 59. These numbers indicate the significant increase of costs for the public health system, the imminent risk of self-medication, and the potential load of pharmaceuticals in the environment, which in its turns will generate ecological impacts and externalities for users of the public water supply by increasing treatment costs, that could be all avoided by the UDS.

\section{- Pharmaceuticals disposal and reverse logistics}

The United States has not implemented a national program for reverse logistics of pharmaceuticals. Initiatives are limited to the local scale and for those the U.S. Food and Drug Administration (FDA) has established three ways of disposing of pharmaceuticals in domestic usage that are no longer needed 60: (i) take-back programs, not available in the whole country; (ii) flushing down the sink or toilet (especially when harmful to others and where take-back is not available) and; (iii) disposal in household trash, except those on the FDA flush list.

In Europe, the European Federation of Pharmaceutical Industries and Associations (EFPIA) outlines the majority of reverse logistics programs for pharmaceuticals 61. Directive 2004/27/CE establishes that State-Members will ensure the creation of adequate collection systems for medicines that are unused or have expired. In 2013, 19 of 27 State-Members have implemented collection systems in their territories, with some national variations 61 . More than half of the collection programs are supported by the pharmaceutical industry, with drugstores as the main collection point 62 .

Canada does not have national regulation regarding the collection of unused/expired medicines 61. Most Canadian provinces base their collection systems on the ability to ensure safety for consumers and children, reduce costs, improve therapeutic results, and diminish potential environmental impacts 63. In the case that collection systems are not available, the Government of Canada recommends disposal of the unused/expired medicines in the household trash. Nevertheless, they do not recommend flushing any medicines down sinks or toilets.

In 2018, the Brazilian Health Regulatory Agency (Anvisa) regulated the practices in managing health systems residues (HSR) when health institutions (hospitals, ambulatories, clinics, etc.), drugstores and medicine distributors dispose of pharmaceuticals drugs (Resolution n. 222/2018). The resolution states that medicines that do not pose radiological, chemical, or biological risks must be dealt with through reverse logistics. Although other national regulations try to implement reverse logistics for pharmaceuticals, they are ineffective.

Regulations and programs to monitor pharmaceuticals in the environment vary among countries, as do the disposal and management of health residues. However, it seems that Brazil lacks initiatives and specific regulation when compared to other countries. Thus, we offer eight recommendations in order for Brazil to minimize the potential environmental/health impacts caused by the inadequate disposal of pharmaceuticals drugs (Box 1). 
Box 1

Suggestions of public policies to be implemented in Brazil regarding pharmaceuticals drugs in environment.

\begin{tabular}{|c|c|c|}
\hline Suggestion & How? & Who? \\
\hline $\begin{array}{l}\text { To disseminate information to users about the } \\
\text { environmental risks that medicine use presents } \\
\text { (consumption and disposal) }\end{array}$ & $\begin{array}{c}\text { Vehicles of communication (television, } \\
\text { radio, social media and orientation in health } \\
\text { establishments) }\end{array}$ & $\begin{array}{l}\text { Brazilian Ministry of Health, Anvisa and } \\
\text { pharmaceutical industry }\end{array}$ \\
\hline $\begin{array}{l}\text { To raise awareness among health professionals } \\
\text { involved in the dispensing and marketing of } \\
\text { medicines }\end{array}$ & Campaigns and events & $\begin{array}{l}\text { Brazilian Ministry of Health, Anvisa and } \\
\text { pharmaceutical industry }\end{array}$ \\
\hline $\begin{array}{l}\text { To teach in the courses of the health area (from } \\
\text { technician to superior) actions of prevention } \\
\text { of disposing of pharmaceutical drugs in the } \\
\text { environment }\end{array}$ & $\begin{array}{l}\text { Inclusion of the theme in curricula of } \\
\text { technical and superior courses }\end{array}$ & $\begin{array}{l}\text { Brazilian Ministry of Education, Brazilian } \\
\text { Ministry of Health, education and } \\
\text { research institutes and universities }\end{array}$ \\
\hline $\begin{array}{l}\text { To make mandatory the presentation of } \\
\text { information about the disposal of the medicine in } \\
\text { its packaging }\end{array}$ & Specific regulation and surveillance & Brazilian Ministry of Health and Anvisa \\
\hline $\begin{array}{l}\text { To call the pharmaceutical industry under its } \\
\text { responsibility as established in the National Solid } \\
\text { Waste Policy }\end{array}$ & Specific regulation and surveillance & Brazilian Ministry of Environment \\
\hline $\begin{array}{l}\text { To effectively adopt the unit-dose system in health } \\
\text { facilities }\end{array}$ & Specific regulation & Brazilian Ministry of Health and Anvisa \\
\hline $\begin{array}{l}\text { To make mandatory the fractioning of prescription } \\
\text { medicines, in the exact amount for the treatment }\end{array}$ & Specific regulation & Brazilian Ministry of Health and Anvisa \\
\hline $\begin{array}{l}\text { To promote the theme of pharmaceutical residues } \\
\text { in schools through environmental education }\end{array}$ & Inclusion of the theme in school curricula & $\begin{array}{l}\text { Brazilian Ministry of Education and } \\
\text { Brazlian Ministry of Health }\end{array}$ \\
\hline $\begin{array}{l}\text { To create an environmental monitoring } \\
\text { prioritization list for pharmaceutical drugs }\end{array}$ & $\begin{array}{l}\text { Partnership between academia, } \\
\text { environmental regulators and those } \\
\text { responsible for production and distribution } \\
\text { for financing and prioritization }\end{array}$ & $\begin{array}{c}\text { Environmental organs of the federal } \\
\text { and state spheres, research institutes, } \\
\text { universities and the pharmaceutical } \\
\text { industry }\end{array}$ \\
\hline $\begin{array}{l}\text { To develop and apply analytical methods for } \\
\text { monitoring pharmaceutical drugs, metabolites } \\
\text { and pharmaceutical degradation products in } \\
\text { water bodies }\end{array}$ & $\begin{array}{l}\text { Partnership between academia, } \\
\text { environmental regulators and those } \\
\text { responsible for production and distribution } \\
\text { for financing and prioritization }\end{array}$ & $\begin{array}{c}\text { Environmental organs of the federal } \\
\text { and state spheres, research institutes, } \\
\text { universities and the pharmaceutical } \\
\text { industry }\end{array}$ \\
\hline
\end{tabular}

Anvisa: Brazilian Health Regulatory Agency.

\section{Final considerations}

The presence of pharmaceuticals drugs in the environment has been repeatedly reported throughout the world in scientific and technical literature. For some pharmaceuticals drugs, there is concrete evidence pointing to their environmental/health impacts, although the effects of the vast majority of these substances remain unknown. As analytical methods, techniques and equipment have developed in recent years, new information on the spread and impact of pharmaceuticals drugs in the environment has helped to better plan of actions and implementation of public policies around the world.

The type and amount of medicine sold in the São Paulo Metropolitan Region indicate the pharmaceuticals drugs that can potentially accumulate in water bodies, especially urban reservoirs. The prioritization of pharmaceuticals drugs both in terms of detection and monitoring in the environment and the water requires the integration of mass sold data with other chemical and environmental attributes of such substances. 
Public policies related to the consumption, disposal and reverse logistics of medicines are critical. Several countries envisage mechanisms to minimize the load of pharmaceuticals into the environment, varying only in specific operational details. In Brazil, national regulations already address this issue. However, the deficit of coverage in the sanitation network compounded by the lack of information of agents working with medicines on how to correctly dispose of it (from users and health professionals to distribution chains and sales) results in ineffective enforcement of existing regulations and greater exposure to environmental/health risks. In addition to possible improvements in legal texts, it is necessary to invest in campaigns to raise awareness of the problem, especially aimed at health professionals involved in dispensing and marketing medicines. If properly instructed, these agents will be able to disseminate the correct medical disposal guidelines to patients and consumers. Besides, it is essential to hold the pharmaceutical industry to account, from the recognition that its products are pollutants and the establishment of an effective reverse logistics structure to supporting the development of techniques and methods of detection, monitoring and remediation of pharmaceuticals, metabolites, and pharmaceuticals degradation products in the environment. In this sense, pharmaceutical industries should help finance the costs of the analytical methods required to assess and monitor pharmaceuticals in the environment by independent organizations.

Finally, the adoption of the UDS may contribute to reducing the environmental impacts of pharmaceuticals, with the additional benefit of minimizing risks of intoxication, self-medication, and consequent reduction in costs. This model has proven to be highly efficient in several countries. If Brazil overcomes this barrier, it could reduce water treatment and monitoring costs and increase the safety of drinking water for the population.

\section{Contributors}

R. B. A. Aragão contributed in the organization and data processing, analysis and discussion of the results, write and review of the paper. D. Semensatto and L. A. Calixto participated in the conception of the project, data analysis, discussion of results, write and review of the paper. G. Labuto collaborated in the project design, data analysis, discussion of results.

\section{Additional informations}

ORCID: Rafaela Barbosa de Andrade Aragão (00000002-4605-8131); Décio Semensatto (0000-00024253-6351); Leandro Augusto Calixto (0000-00031776-7470); Geórgia Labuto (0000-0002-54038974).

\section{Acknowledgments}

The authors are grateful to Close-Up International for providing pharmaceutical sales data, to São Paulo State Research Foundation (FAPESP) for granting (2016/06271-4 and 2019/04319-8), and to Daniel Colman for revising the text. 


\section{References}

1. Hoekstra AY, Mekonnen MM, Chapagain AK, Mathews RE, Richter BD. Global monthly water scarcity: blue water footprints versus blue water availability. PLoS One 2012; 7:e32688.

2. Bartram J, Cairncross S. Hygiene, sanitation, and water: forgotten foundations of health. PLoS Med 2010; 7:e1000367.

3. Gavrilescu M, Demnerová K, Aamand J, Agathos S, Fava F. Emerging pollutants in the environment: present and future challenges in biomonitoring, ecological risks and bioremediation. N Biotechnol 2015; 32:147-56.

4. Geissen V, Mol H, Klumpp E, Umlaufd G, Nadale M, van der Ploeg M, et al. Emerging pollutants in the environment: a challenge for water resource management. International Soil and Water Conservation Research 2015; 3:57-65.

5. Grenni P, Ancona V, Caracciolo AB. Ecological effects of antibiotics on natural ecosystems: a review. Microchem J 2018; 136:25-39.

6. IMS Institute for Healthcare Informatics. Global medicines use in 2020: outlook and implications. Parsippany: IMS Institute for Healthcare Informatics; 2015.

7. Azuma T, Nakada N, Yamashita N, Tanaka H. Evaluation of concentrations of pharmaceuticals detected in sewage influents in Japan by using annual shipping and sales data. Chemosphere 2015; 138:770-6.

8. Oosterhuis M, Sacher F, ter Laak TL. Prediction of concentration levels of metformin and other high consumption pharmaceuticals in wastewater and regional surface water based on sales data. Sci Total Environ 2013; 442:3808.

9. Pereira AMPT, Silva LJG, Lino CM, Meisel LM, Pena A. A critical evaluation of different parameters for estimating pharmaceutical exposure seeking an improved environmental risk assessment. Sci Total Environ 2017; 603:226-36.

10. Almeida GA, Weber RR. Fármacos na Represa Billings. Saúde \& Meio Ambiente 2006; 6:7-12.

11. Cotrim MEB, Martins EAJ, Furusawa HA, Shihomatsu HM, Monteiro LR, Lebre DT, et al. Qualidade ecológica da Represa Guarapiranga: água e sedimentos superficiais: multitraçadores ambientais - metais, elementos-traço, interferentes endócrinos, HPAs e fármacos. In: Bicudo C, Bicudo DC, organizadores. 100 anos da Represa Guarapiranga: lições e desafios. Curitiba: Editora CRV; 2017. p. 309-82.

12. Goswami L, Kumar RV, Borah SN, Manikandan NA, Pakshirajan K, Pugazhenthi G. Membrane bioreactor and integrated membrane bioreactor systems for micropollutant removal from wastewater: a review. Journal of Water Process Engineering 2018; 26:314-28.

13. Ministério da Saúde. Formulário terapêutico nacional 2010: Rename 2010. 2a Ed. Brasília: Ministério da Saúde; 2010.
14. Agência Nacional de Vigilância Sanitária. Guia de medicamentos genéricos. Brasília: Agência Nacional de Vigilância Sanitária; 2001.

15. EPUC. Dicionário de especialidades farmacêuticas. 44a Ed. Rio de Janeiro: Editora de Publicações Científicas; 2016.

16. Pamplona JH, Oba ET, Silva TA, Ramos LP, Ramsdorf WA, Cestari MM, et al. Subchronic effects of dipyrone on the fish species Rhamdia quelen. Ecotoxicology and Environmental Safety 2011; 74:342-9.

17. Peña-Guzmán C, Ulloa-Sánchez S, Mora K, Helena-Bustos R, Lopez-Barrera E, Alvarez J, et al. Emerging pollutants in the urban water cycle in Latin America: a review of the current literature. J Environ Manage 2019; 237:40823.

18. Santos CEM, Nardocci AC. Prioritization of pharmaceuticals in drinking water exposure based on toxicity and environmental fate assessment by in silico tools: an integrated and transparent ranking. Comput Toxicol 2019; 9:12-21.

19. Martínez-Bueno M, Gomez M, Herrera S, Agüera A, Fernández-Alba A. Occurrence and persistence of organic emerging contaminants and priority pollutants in five sewage treatment plants of Spain: two years pilot survey monitoring. Environ Pollut 2012; 164:267-73.

20. Semensatto D, Asami T. Além dos índices numéricos: a qualidade da água da Represa Guarapiranga ao longo do tempo. In: Bicudo C, Bicudo DC, editors. 100 anos da Represa Guarapiranga: lições e desafios. Curitiba: Editora CRV; 2017. p. 383-400.

21. Gong L, Goswami S, Giacomini KM, Altman RB, Klein TE. Metformin pathways: pharmacokinetics and pharmacodynamics. Pharmacogenet Genomics 2012; 22:820-7.

22. Lu CY, Emmerick ICM, Stephens P, Ross-Degnan D, Wagner AK. Uptake of new antidiabetic medications in three emerging markets: a comparison between Brazil, China and Thailand. J Pharm Policy Pract 2015; 8:1-8.

23. Almeida-Pititto B, Dias ML, Moraes ACF, Ferreira SRG, Franco DR, et al. Type 2 diabetes in Brazil: epidemiology and management. Diabetes Metab Syndr Obes 2015; 8:17-28.

24. Borges NB, Ferraz MB, Chacra AR. The cost of type 2 diabetes in Brazil: evaluation of a diabetes care center in the city of São Paulo, Brazil. Diabetol Metab Syndr 2014; 6:122.

25. Vancura A, Bu P, Bhagwat M, Zeng J, Vancurova I. Metformin as an anticancer agent. Trends Pharmacol Sci 2018; 39:867-78.

26. Seifarth C, Schehler B, Schneider HJ. Effectiveness of metformin on weight loss in nondiabetic individuals with obesity. Exp Clin Endocrinol Diabetes 2012; 121:27-31. 
27. Briones RM, Sarmah AK, Padhye LP. A global perspective on the use, occurrence, fate and effects of anti-diabetic drug metformin in natural and engineered ecosystems. Environ Pollut 2016; 219:1007-20.

28. Niemuth NJ, Klaper RD. Emerging wastewater contaminant metformin causes intersex and reduced fecundity in fish. Chemosphere 2015; 135:38-45.

29. Guo J, Sinclair CJ, Selby K, Boxall ABA. Toxicological and ecotoxicological risk-based prioritization of pharmaceuticals in the natural environment. Environ Toxicol Chem 2016; 35:1550-9.

30. Moermond CTA, Smit CE. Derivation of water quality standards for carbamazepine, metoprolol, and metformin and comparison with monitoring data. Environ Toxicol Chem 2016; 35:882-8.

31. Straub JO, Caldwell DJ, Davidson T, D’Aco V, Kappler K, Robbinson PF, et al. Environmental risk assessment of metformin and its transformation product guanylurea. I. Environmental fate. Chemosphere 2019; 216:844-54.

32. Chen Y, Vymazal J, Březinová T, Koželuhc M, Kulec L, Huang J, et al. Occurrence, removal and environmental risk assessment of pharmaceuticals and personal care products in rural wastewater treatment wetlands. Sci Total Environ 2016; 566/567:1660-9.

33. Lima D, Tonucci M, Libânio M, Aquino S. Fármacos e desreguladores endócrinos em águas brasileiras: ocorrência e técnicas de remoção. Eng Sanit Ambient 2017; 22:1043-54.

34. Mazaleuskaya LL, Sangkuhl K, Thorn CF, FitzGerald GA, Altman RB, Klein TE. PharmGKB summary: pathways of acetaminophen metabolism at the therapeutic versus toxic doses. Pharmacogenet Genomics 2015; 25:416-26.

35. Daughton CG. The Matthew Effect and widely prescribed pharmaceuticals lacking environmental monitoring: case study of an exposureassessment vulnerability. Sci Total Environ 2014; 466/467:315-25.

36. Gelotte CK. An open-label, randomized, fourtreatment crossover study evaluating the effects of salt form, acetaminophen, and food on the pharmacokinetics of phenylephrine. Regul Toxicol Pharmacol 2018; 95:333-8.

37. Robles-Molina J, Gilbert-López B, GarcíaReyes JF, Molina-Díaz A. Monitoring of selected priority and emerging contaminants in the Guadalquivir River and other related surface waters in the province of Jaén, South East Spain. Sci Total Environ 2014; 479/480:24757.

38. Estévez E, Cabrera MC, Molina-Díaz A, Robles-Molina J, Palacios-Díaz MP. Screening of emerging contaminants and priority substances $(2008 / 105 / E C)$ in reclaimed water for irrigation and groundwater in a volcanic aquifer (Gran Canaria, Canary Islands, Spain). Sci Total Environ 2012; 433:538-46.
39. Martínez-Bueno M, Uclés S, Hernando MD, Fernández-Alba A. Development of a solventfree method for the simultaneous identification/quantification of drugs of abuse and their metabolites in environmental water by LCMS/MS. Talanta 2011; 85:157-66.

40. Madden JC, Enoch SJ, Hewitt M, Cronin MTD. Pharmaceuticals in the environment: good practice in predicting acute ecotoxicological effects. Toxicol Lett 2009; 185:85-101.

41. Silva RM, Chaves GC, Chaves LA, Campos MR, Luiza VL, Bertoldi AD, et al. Farmácia Popular Program: pharmaceutical market analysis of antihypertensive acting on the renin-angiotensin system medicines. Ciênc Saúde Colet 2017; 22:2501-12.

42. Pereira CDS, Maranho LA, Cortez FS, Pusceddu FH, Santos AR, Ribeiro DA, et al. Occurrence of pharmaceuticals and cocaine in a Brazilian coastal zone. Sci Total Environ 2016; 548/549:148-54.

43. Starling MCV, Amorim CC, Leão MMD. Occurrence, control and fate of contaminants of emerging concern in environmental compartments in Brazil. J Hazard Mater 2019; 372:1736.

44. Cortez FS, Souza LS, Guimarães LL, Almeida JE, Pusceddu FH, Maranho LA, et al. Ecotoxicological effects of losartan on the brown mussel Perna perna and its occurrence in seawater from Santos Bay (Brazil). Sci Total Environ 2018; 637/638:1363-71.

45. Adachi A, Okano T. Generation of cyanide ion by the reaction of hexamine and losartan potassium with sodium hypochlorite. J Heal Sci 2008; 54:581-83.

46. Adeel M, Song X, Wang Y, Francis D, Yang Y. Environmental impact of estrogens on human, animal and plant life: a critical review. Environ Int 2017; 99:107-19.

47. Pflug NC, Hankard MK, Berg SM, O'Connor M, Gloer JB, Kolodziej EP, et al. Environmental photochemistry of dienogest: phototransformation to estrogenic products and increased environmental persistence via reversible photohydration. Environ Sci Process Impacts 2017; 19:1414-26.

48. Golovko O, Šauer P, Fedorova G, Kroupová HK, Grabic R. Determination of progestogens in surface and waste water using SPE extraction and LC-APCI/APPI-HRPS. Sci Total Environ 2018; 621:1066-73.

49. Liu Z-H, Ogejo JA, Pruden A, Knowlton KF. Occurrence, fate and removal of synthetic oral contraceptives (SOCs) in the natural environment: a review. Sci Total Environ 2011; 409:5149-61.

50. Michael I, Rizzo L, McArdell CS, Manaia CM, Merlin C, Schwartz T, et al. Urban wastewater treatment plants as hotspots for the release of antibiotics in the environment: a review. Water Res 2013; 47:957-95. 
51. World Health Organization. Pharmaceuticals in drinking-water. Geneva: World Health Organization; 2012.

52. United States Environmental Protection Agency. The fourth unregulated contaminant monitoring rule. Washington DC: United States Environmental Protection Agency; 2016.

53. Loos R, Marinov D, Sanseverino I, Napierska D, Lettieri T. Review of the 1st Watch List under the water framework directive and recommendations for the 2nd Watch List. Luxembourg: Publications Office of the European Union; 2018.

54. European Commission. European Union strategic approach to pharmaceuticals in the environment. Brussels: European Comission; 2019.

55. Metz F, Ingold K. Politics of the precautionary principle: assessing actors' preferences in water protection policy. Policy Sci 2017; 50:72143.

56. Zidek A, Macey K, Mackinnon L, Patel M, Poddalgoda D, Zhang Y. A review of human biomonitoring data used in regulatory risk assessment under Canada's Chemicals Management Program. Int J Hyg Environ Health 2017; 220:167-78

57. World Health Organization. Promoting rational use of medicines: core components WHO policy perspectives on medicines. Geneva: World Health Organization; 2002.
58. Mieiro DB, Oliveira EBC, Fonseca REPD Mininel VA, Zem-Mascarenhas SH, Machado RC. Strategies to minimize medication errors in emergency units: an integrative review. Rev Bras Enferm 2019; 72:307-14.

59. Murakami I, Ribeiro-Neto LM, Silva AM. A importância do fracionamento de medicamentos para o SUS: um estudo piloto. Rev Bras Farm 2012; 93:221-4.

60. U.S. Food and Drug Administration. Where and how to dispose of unused medicines. Washington DC: U.S. Food and Drug Administration; 2019.

61. Hiratuka C, Vargas MA, Fracalanza P, Rosandiski EN, Corazza RI, Oliveira ALR. Logística reversa para o setor de medicamentos. Brasília: Associação Brasileira de Desenvolvimento Industrial; 2013.

67. Health Care Without Harm. Unused pharmaceuticals where do they end up? A snapshot of European collection schemes. Brussels: Health Care Without Harm; 2013.

63. Daughton CG. Cradle-to-cradle stewardship of drugs for minimizing their environmental disposition while promoting human health. II. Drug disposal, waste reduction, and future directions. Environ Health Perspect 2003; 111:775-85. 


\section{Resumo}

A poluição da água tem preocupado cada vez mais as autoridades responsáveis pelo planejamento e execução das políticas públicas no Brasil. Esta pesquisa qualitativa discute os produtos farmacêuticos mais vendidos na Região Metropolitana de São Paulo, Brasil, e compara as politicas públicas focadas em produtos farmacêuticos e questões ambientais, entre países e regiões. Foram coletados e processados os dados fornecidos pela Close-Up International sobre vendas de medicamentos na Grande São Paulo entre abril de 2016 e abril de 2017, para identificar e quantificar esses produtos. Os 300 medicamentos mais vendidos na Grande São Paulo pertencem a 26 classes terapêticas e incluem 159 fármacos. Os produtos farmacêuticos mais vendidos pertencem ao grupo dos anti-inflamatórios não esteroides (AINES), representando aproximadamente 44,3\% do total. Os dez produtos farmacêuticos mais vendidos somam 1.200 toneladas. A dipirona liderou o ranking em termos de massa, com cerca de 488 toneladas, seguida pela metformina, com 310 toneladas comercializadas. As politicas públicas focadas nos produtos farmacêuticos e sua presença no meio ambiente ainda requerem ajustes, mesmo nos paises desenvolvidos. Não existe uma norma internacional para lidar com essa questão, e cada país adota a política pública mais adequada para o contexto local. $O$ Brasil já dispõe de alguma legislação sobre o tema, mas ainda faltam políticas públicas efetivas $e$ uma melhor conscientização dos atores envolvidos. Portanto, há uma necessidade evidente de melhorar o sistema de logística reversa, com orientação dos consumidores em relação ao descarte adequado dos medicamentos não utilizados ou vencidos e a adoção do sistema de dose unitária como estratégia terapêutica.

Poluição da Água; Monitoramento Ambiental; Saúde Ambiental; Politica Ambiental; Política de Saúde

\section{Resumen}

La contaminación del agua ha sido una creciente preocupación para las autoridades responsables de planificar y ejecutar politicas públicas. Esta investigación cualitativa trata sobre los productos farmacéuticos más vendidos en la Región Metropolitana de São Paulo, Brasil, y además compara las politicas públicas centradas en cuestiones farmacéuticas y ambientales entre países/regiones. En este sentido, los datos proporcionados por CloseUp International, relacionados con las ventas de medicinas en la Región Metropolitana de São Paulo entre abril/2016y abril/2017, se recogieron $y$ presentaron para identificar y cuantificar los productos farmacéuticos. Las 300 medicinas más vendidas en la Región Metropolitana de São Paulo se incluyeron en 26 clases terapéuticas, que incluyeron 159 medicamentos. El grupo de productos farmacéuticos más vendido es el de los medicamentos antiinflamatorios no esteroides (AINE), representando aproximadamente un 44,3\% del total. Los 10 productos farmacéuticos más vendidos llegaron a alcanzar las 1.200 toneladas. La dipirona está en primer lugar, alrededor de 488 toneladas, a la que le sigue la metformina con cerca de 310 toneladas comercializadas. Las politicas públicas centradas en productos farmacéuticos y medioambiente todavia necesitan ajustes para mejorar su fortalecimiento, incluso en los países desarrollados. No existe un estándar internacional sobre cómo gestionar este asunto, cada país adopta las politicas públicas que mejor se ajustan a su entorno. Brasil, a pesar de contar con algo de legislación que se centra en esta cuestión, todavía adolece de politicas públicas efectivas, así como una falta de sensibilización de los agentes responsables. En este aspecto, es evidente la necesidad de mejorar el sistema de logística inversa, así como la orientación al consumidor para desechar adecuadamente las medicinas no usadas/caducadas, y la adopción de un sistema de dosis unitarias como estrategia terapéutica.

Contaminación del Agua; Monitoreo de

Ambiente; Salud Ambiental; Politica

Ambiental; Politica de Salud
Submitted on $02 /$ Oct $/ 2019$

Final version resubmitted on 29/Mar/2020

Approved on 27/Apr/2020 